\title{
Corela
}

Cognition, représentation, langage

3-1 | 2005

Vol. $3, n^{\circ} 1$

\section{La portée pragmatique de Have $a$ V.}

\section{Emmanuelle Roussel}

\section{OpenEdition}

\section{Journals}

Édition électronique

URL : http://journals.openedition.org/corela/496

DOI : $10.4000 /$ corela.496

ISSN : 1638-573X

\section{Éditeur}

Cercle linguistique du Centre et de l'Ouest - CerLICO

\section{Référence électronique}

Emmanuelle Roussel, « La portée pragmatique de Have a V. », Corela [En ligne], 3-1 | 2005, mis en ligne le 04 juillet 2005, consulté le 07 mai 2019. URL : http://journals.openedition.org/corela/496 ; DOI : $10.4000 /$ corela.496

Ce document a été généré automatiquement le 7 mai 2019.

\section{(c) (i) (2)(2)}

Corela - cognition, représentation, langage est mis à disposition selon les termes de la licence Creative Commons Attribution - Pas d'Utilisation Commerciale - Partage dans les Mêmes Conditions 4.0 International. 


\title{
La portée pragmatique de Have a $\mathrm{V}$.
}

\author{
Emmanuelle Roussel
}

\section{Introduction}

1 La réflexion que je présente ici porte sur la structure have $a V$, cas typique de localisation (puisque construit sur have), ne soulevant donc a priori aucun problème d'interprétation particulier.

2 L'analyse que je propose se démarque des différents travaux traitant de la construction ${ }^{1}$, dans la mesure où je souhaite traiter prioritairement du sujet grammatical de même que du statut de cette construction dans une perspective pragmatique.

3 Il me semble en effet possible de considérer que la portée discursive de have a $V$ nait de la similarité (dont je vais montrer qu'elle n'est que de surface) de l'expression avec have a $\mathrm{N}$, structure (de base) de l'anglais. Le code commun aux utilisateurs de la langue est un creuset d'où émergent des relations "inter-énonciateurs " reposant, en grande part, sur ce que j'appelle de "l'implicite signifiant ". C'est ce que je souhaite montrer pour have a $V$, auquel j'applique une vision d'ensemble, en l'opposant en bloc à have a $N$.

\section{La localisation}

\subsection{Principe général}

4 Le terme de "localisation", au sens large, définit une relation de repérage de deux termes l'un par rapport à l'autre. Ce principe de mise en relation d'éléments, qui s'oppose à la fusion d'éléments, se rencontre déjà chez Aristote, pour lequel (Livre B : 117) :

[En effet,] les qualités des choses, leurs mouvements, leurs relations, leurs positions, leurs proportions diverses n'expriment, à ce qu'il semble, la substance pour aucun d'eux. Toutes ces déterminations sont toujours attribuées à un certain sujet ; mais elles ne sont point ce sujet lui-même. 
valeurs des occurrences qu'il sert à construire étant pour leur part liées au contexte (J. Bouscaren 1982: 55). Il met ainsi en place cette relation de repérage, que ce qu'il introduit soit de nature nominale (I have a house) ou verbale (I have broken the vase). Concrètement, have permet de repérer le constituant qui se situe à sa droite par rapport à celui qui se situe à sa gauche (S). Dire que “... est localisé par rapport à $S$ ” ou que “... est localisé par rapport au sujet" signifie que la chose en question est présentée comme appartenant à la sphère du sujet, sans toutefois qu'elle ne fusionne avec ce sujet. Chacune des deux entités conserve ses caractéristiques propres et acquiert sa valeur dans son rapport à l'autre. Ainsi, dans toute construction en have, le sujet se trouve valorisé par cet apport de caractéristiques externes.

Par conséquent, have apparait également comme un opérateur de thématisation du sujet (J.Bouscaren 1982: 63). En effet, la subordination du complément nominal ou du participe passé dans la sphère du sujet n'est autre qu'une mise au second plan : le sujet se trouve ipso facto valorisé. Have permet un tel fonctionnement car étymologiquement il signifie hold in the hand (racine proto-indo-européenne PIE *kap- : to grasp. En dépit d'une similitude de forme et de sens, have n'est pas lié au latin habere), d'où son utilisation pour l'expression de la possession, autrement dit l'intégration d'une chose dans la sphère d'une autre.

7 Il s'avère toutefois que des réticences ont été exprimées quant au choix même du terme de thématisation mis en place par have. La thématisation traite du thème de l'énoncé : ce dont l'on parle ou l'information ancienne, si l'on souhaite en donner une définition satisfaisante pour le plus grand nombre. La thématisation ne traite pas de la relation proprement dite qui se crée entre les constituants. La thématisation relève davantage d'une fin que d'un moyen, en ce sens qu'elle ne justifie pas la mise en relation, elle n'en prend pas l'initiative. C'est la raison pour laquelle C. Boisson (1981: 160) par exemple préfère le terme "d'empathie" pour définir le repérage mis en place par have dans certains énoncés. Parallèlement à une mise en relation de deux termes et une valorisation du sujet, have est donc également présenté en termes de vecteur de l'expression d'un point de vue.

Dans tout ce qui précède, l'idée d'empathie me semble tout particulièrement convenir aux constructions have $a V$. Bien qu'elle ait néanmoins déjà été évoquée (A. Wierzbicka $1988: 348)^{2}$, je souhaite formuler une autre hypothèse selon laquelle la valeur de have $a V$ viendrait non pas uniquement du fait que son sujet est à la fois l'agent et celui qui fait l'expérience de l'action dénotée par la structure, mais également des conditions du rapport de ce [sujet/agent/siège de l'expérience] à l'Autre. La valeur de have a $V$ se mettrait en place parce que la structure s'élabore sur have a $N$ (type : I have a house), tout en s'en éloignant. De ce contraste naîtrait la spécificité de have $a \mathrm{~V}$.

\subsection{Have dans have a $V$}

La localisation telle qu'elle vient d'être présentée sous-tend à l'évidence le sémantisme des expressions construites sur le modèle have $a$ V. Modèle différemment analysé, comme nous allons le voir, toutefois les études portent inévitablement leur attention sur le segment qui suit have. Ce segment est présenté comme étant celui sur lequel repose la majeure partie du sémantisme, notamment en raison de sa nature de verbe nominalisé. 
Cet objet qui n'est pas totalement nominal (ou qui n'est plus totalement verbal) va communiquer le dynamisme contenu dans le verbe dont il est issu.

C'est ainsi que J. Bouscaren (1982 : 59) y voit un processus et non plus un état. Le repérage se fait entre un procès et son agent. La construction indique une propriété permanente ou une action. Et les expressions: "se comportent comme les verbes sous-jacents à des prédicats nominalisés".

Toujours à propos de ces constructions have $a V$, nous pouvons lire dans le Collins Cobuild (1992 : 667) la chose suivante, assez surprenante au demeurant :

Have is frequently used with nouns as objects, where the word 'have' has very little meaning in itself, but where most of the meaning is given by the noun. The function of 'have' is thus to provide a verb for the structure and very little else. In this group, there is always an equivalent verb for the 'have + noun' structure, so that 'to have a look' means almost the same as 'to look'. This structure is often chosen to emphasize that an action or event has a definite beginning or end, or in order to add more information about the noun. Have is used with nouns that describe actions ('go and have a look'...) [...] used to form nouns from verbs ('it's worth having a try').

Chez R. Huddleston (2002: 111) encore nous trouvons :

In the have a - construction, have is dynamic, it expresses an event rather than a state. In 'I had a swim', it is used as a 'light verb': the main semantic contents is the following noun.

11 On ne peut manquer d'observer dans les lignes qui précèdent une imprécision quant à la nature exacte du constituant introduit par $a$. Il est question de verbe $(V)$ et / ou de nom ( $N$ ). Ceci est à la fois déroutant et symptomatique de ce que je souhaite montrer: on recherche une unité, mais il n'en n'existe pas.

La même inconsistance est de mise dans le dictionnaire Macmillan (2003 : 654) :

Used as a transitive verb for talking about actions and experiences: 'Let's have a swim before lunch', 'I had a good time at the party.'

12 Le second énoncé ne répond pas aux critères sémantiques de have tel qu'il apparaît dans have a drink, mais à ceux qui sont le sien dans have a house, dans la mesure où l'on ne retrouve pas le lien to swim $\leftrightarrow$ to have a swim dans to time $\leftrightarrow$ to have a good time. ${ }^{3}$

Dans la structure à l'étude, have n'a cependant pas le même sens que celui qu'il peut avoir dans I have a house, où c'est l'expression de la possession qui prime. Dans have a $V$ en effet, have s'éloigne sémantiquement de hold (have a meeting), possess (have a house), own (have a business), enjoy (have a good reputation), suffer (have a shock), experience (have an illness), undergo (have medical treatment), produce (have a baby) ou encore de ce que have traduit dans les locutions telles have blue eyes ("présenter en soi ") ou have daughters (relations de parenté, d'affection ou de hiérarchie) qui constituent ses principaux sens. Il prend celui, plus général, de “ faire l'action de ". C'est le trait + dynamique de have qui y est ainsi sélectionné, au détriment du trait - dynamique ("posséder", par exemple, c'est "être dans l'état résultant de l'acquisition "). Ce n'est donc pas a priori le même have, ou en tout état de cause, le même emploi de have qui est à l'œuvre dans le cas qui nous préoccupe.

Car have $a V$ est bien une structure à part. De style très familier (langage de tous les jours en Australie) elle a ceci de particulier qu'elle véhicule un sens précis, opposé à celui du $V$ qu'elle contient quand il est utilisé seul. Ainsi, have a drink, have a walk sont-ils présentés ici comme étant sémantiquement différents de drink et walk. Nous y reviendrons.

Dans son article " Why can you have a drink when you can't * have an eat? ", A. Wierzbicka (1987: 293-357) délimite précisément son champ d'étude en ne conservant que: have a 
drink (a bite, a suck, a chew, a nibble), a walk (a stroll), a swim, a lie-down, a try, a look (for), a listen (to), a smell (of), a feel (for), a read, a scribble, a cry, a wash, a sip, a cuddle, a chat, a run, a use [ju:z]. Ce dernier emploi étant typiquement australien (sa prononciation indique bien le statut verbal de use. Nominal, il serait prononcé [ju:s]), comme d'autres non analysés mais recensés : have a choose, have a bitch, a beef, a gab, a yarn. Sa sélection diffère néanmoins de celle de R. Quirk (1985) qui inclut have a bash ("vas-y, essaie toujours !"), ou de celle de R. Huddleston (2002) avec : have a quarrel (qui équivaut à une construction have a $N$ pour A. Wierzbicka), a sleep, a guess, a grumble, a fight (with), a meeting (with). Indétermination assez déconcertante.

Pour en revenir à A. Wierzbicka, elle met en évidence la richesse sémantique de la locution, richesse en partie liée à have. ${ }^{4}$ Selon l'auteur, la locution implique :

- une perspective de sensation subjective,

- une présentation du procès comme limité dans le temps (à la différence du verbe simple correspondant),

- procès ne pouvant avoir de but externe (soit le procès est sans but, soit il vise une sensation propre à l'agent),

- ayant par conséquent un objectif interne potentiel et

- pouvant, enfin, être réitéré.

- La construction exclut un objectif différent de l'agent lui-même, et

- suggère que l'activité est plaisante,

- ou encore qu'elle est potentiellement bonne pour le patient.

- Ce qui est dit de l'objet est une manière de dire quelque chose sur le sujet (A. Wierzbicka : $300) .^{5}$

En substance, have a $V$ rassemble essentiellement trois traits spécifiques: l'agentivité, l'association au sujet et le bénéfice que la réalisation du procès dénoté par le verbe représente pour le sujet.

Plutôt que de m'en tenir à cette conclusion, exacte dans le propos mais uniquement centrée sur une collocation précise de constituants exigeant pas moins de dix critères différents (selon A. Wierzbicka) ${ }^{6}$, j'ai souhaité sortir de cette configuration. En effet, la multiplicité des critères de catégorisation, la confusion quant à la nature exacte de ce qui suit have m'ont poussée à me demander si la justification de have a $V$ (existence même de la locution et sémantisme spécifique), plutôt que de résider dans une étude fermée de ses trois constituants (have $+a+V$ ), ne pourrait en revanche se trouver "à l'extérieur" de la locution. C'est-à-dire dans son rapport aux autres constructions en have, et notamment have a $N$ (type have a house). Il est légitime me semble-t-il de s'interroger sur la raison profonde pour laquelle la classification des occurrences de have $a$.. est problématique. Entre have a drink (have a $V$ ) et have a shower (have a $N$ ), have a drink est recensé have a $V$ pour A. Wierzbicka, mais have a $N$ dans les dictionnaires ou grammaires. Have a shower comme have a N pour Wierzbicka mais have a V pour R. Huddleston (2002: 290) par exemple. Il est également possible de s'interroger sur la raison pour laquelle on oppose ces deux dernières structures dans la mesure où $V$ semble toujours dérivé, ou dérivable, de $N$, et réciproquement.

Par conséquent, c'est une vision d'ensemble de la locution have a $V$ que je souhaite proposer, à partir de l'examen d'un échantillon type d'occurrences citées par A. Wierzbicka (celles que nous sommes amenés à rencontrer le plus fréquemment). Mon étude traite de have a drink comme de have a shower, et vise à en extraire un (nouvel) 
invariant, commun et spécifique à la fois. Je pense que l'on peut définir ces deux types de construction d'après un critère unique.

Pour ce faire j'ai, dans un premier temps, comparé les occurrences de have $a V$ et de $V$ (toujours selon le classement de A. Wierzbicka), à la recherche d'un effet de sens précis qui se dégagerait de have a $V$. Puis, j'ai confronté les résultats obtenus avec des occurrences écrites et orales extraites de mon propre corpus afin de vérifier le caractère tangible des critères retenus.

\section{Analyse globale}

\section{1. Confrontation de have $a$ et de $V$}

La première remarque que l'on peut faire concernant les constructions de type have $a V$ concerne leur fréquence. Le nombre d'occurrences rencontrées ${ }^{7}$ est en définitive relativement faible, contrairement à ce que l'on pourrait croire a priori. Seuls have a look (1920 occurrences), have a drink (293 occurrences) et have a chat (129 occurrences) reviennent assez régulièrement. Pour le reste, les chiffres sont moins importants (have $a$ try: 28; have a think/listen to: 26; have a walk: 18; have a run: 15; have a read: 14; have a wash: 13; have a swim/a cuddle/a shave: 8 ; have a pee: 7; have a sip: 4; have a stroll/a smell (of)/a cry: 3; have a lie-down: 2; have a scribble/a cough: 1; et même have a yawn: 0 - pourtant recensé par A. Wierzbicka).

L'examen approfondi du sémantisme des constructions have $a V v s V$ révèle la présence d'une différence, have a $V$, hormis les propriétés mises en évidence par A. Wierzbicka, véhiculant dans chacun de ses emplois un message spécifique.

Ainsi, to have a drink qui, en règle générale, est restreint à l'absorption d'une boisson alcoolisée (often used to refer to an alcoholic drink ${ }^{8}$ ), là où to drink renvoie davantage à l'action d'ingérer un liquide par la bouche (to take liquid into your body through your mouth). Et lorsqu'il est question d'alcool, to drink renvoie soit à une action régulière, soit à de grandes quantités (to drink alcohol, especially regularly or in larges quantities). Nous observons donc que l'équivalence absolue n'existe pas entre les deux structures (les constituants soulignés relayent la spécificité sémantique illustrée par have a drink) :

(1) Let's have a drink, shall we?' 'No whisky for me, I'm driving. (énoncé entendu)

(2) He arranged for us all to have a drink with him at the Roebuck. (A6E 1200)

(3) We sit in the bar there and have a drink and someone might discreetly tell us who's upstairs. (AJY 2227)

(4) In the evening, Derek went into a bar to have a drink. (CCC 438)

(5) I'm good, I'm not drinking in the week I'm not, I don't really have a drink do you have a drink? (KB2 1568)

(6) There are a lot of people who chat to a waitress if they're a bloke or chat to the whatever it is if they're girls but er in a friendly way, who will have a drink but will not be paralytically drunk, who may watch television or a, you know, film or theatre or something if it's appropriate but won't get twitched if it isn't? (KC3 389)

(7) We went along not allowed to have a drink and all that. (KPG 4351)

To have a wash est également clairement spécifique. L'expression signifie " to scrub, that is to rub hard in order to clean something, often using a stiff brush and water, or another liquid ". Le sens de to wash est différent: to clean something because it is dirty, using water and soap or detergent. Quand il s'applique à un être humain, qu'il entre dans une structure intransitive (to wash) ou transitive directe (to wash part of one's body), il renvoie à 
l'action de nettoyer le visage et les mains en particulier. Donc, to have a wash réfère implicitement à l'ensemble du corps, ce que ne fait pas to wash. En outre, to have a wash suggère la nécessité de "frotter", ce qui n'est pas le cas pour to wash. Le contexte sera par conséquent toujours explicite :

(8) Can't I have a wash and a change first, sergeant ? (ACE 701)

(9) Do I have a wash especially for Dorothea,' she glanced up sharply, 'with the scented soap? (AD1 1726)

(10) When you have a wash it wakes you up, doesn't it? (KDY 1041)

Il en est de même pour to have a walk (a short journey which you make by walking, usually for pleasure) qui se démarque de to walk (to move along fairly slowly by putting one foot in front of the other on the ground). La notion de promenade, sans finalité, est propre à have a V. Elle est absente de V :

(11) It is time to leave the capital and have a walk; let us rise betimes. (B1N 1568)

(12) Want to have a walk round?, he invited. (G1D 2444)

(13) 'Then if the weather's OK we can have a walk in the afternoon and reminisce about the days when women stayed at home and looked after their menfolk.' (HTG 1197)

(14) 'Cos I thought it would, it was such a warm day I thought it would be quite nice for him to have a walk and see if he was alright.' (KBW 8770)

(15) Anyone who's vigilant knows what's going on and they're aware of what's happening, so again it shows that we must do something as they said on that motorway, the thing to do when you feel yourself going into drowsiness, is stop the car perhaps, get out and have a walk round, do something, I know in the past when I've felt myself going off to sleep in those situations, I've been pinching myself and, and really making yourself do something rather than just sitting there doing nothing, cos that's the way we just go off and get lowered into sleep and our lives are involved in this, we've read and heard about people that have gone to sleep on motorways, haven't they? (KBX 687)

Dans ce dernier énoncé, s'ajoute une justification du recours à have a walk. Si bien que l'on pourrait presque y voir une relation de cause à effet: 'if you feel yourself going into drowsiness, then have a walk'.

To have a swim réfère à an occasion when you swim, tandis que to swim signifie to move through water by making movements with your arms and legs. La différence de sens est moins nette cette fois, mais elle existe néanmoins : to have a swim renvoie à une occurrence précise qui correspond à la validation de la prédication to swim. C'est-à-dire que to have a swim vise davantage la réalisation du procès swim que ne peut le faire to swim qui renvoie plus aux mécanismes physiques liés au mouvement dans l'eau. Par ailleurs, l'occurrence en question a une incidence particulière en situation:

(16) 'So I plan to do a couple of hours' writing in the morning then go off and have a swim in the afternoon.' (CH1 5996)

(17) 'Why don't you come down and have a swim? (FB9 830)

(18) 'It's a perfect opportunity to have a swim. (JXT 1644)

(16) réfère à une intention, (17) est une suggestion: nous avons là deux procédés en affinité avec la visée d'une relation prédicative.

To have a cry (a period of time when you have tears coming from your eyes, especially because you are sad) se comporte de manière similaire (a period of time) et intègre une autre spécificité, la tristesse. Quand on dit to have a cry, cela signifie que l'on est triste. Alors que l'on peut pleurer (to cry) de douleur, de peur, de désarroi et éventuellement de tristesse. To cry n'implique pas en priorité le sème de tristesse : 
(19) But I still have a cry, sometimes, when I realize that my mother is dead; and that's years after. (BLW 956)

(20) Then a girl came upstairs and said, "Oh don't be silly, have a cry on my shoulder," and she helped me to settle. (FU1 2407)

En (20), l'épaule symbolise le lieu du réconfort.

31 To have a lie-down est directement et clairement répertorié comme expression familière. Elle implique également que le lieu du (bref) repos est le lit : a short rest - usually in bed. To lie down s'intéresse davantage au changement de position: to move into a horizontal position, usually in order to rest or sleep. Les deux expressions ont bien leur spécificité. Et ce n'est que l'usage qui enseigne à un énonciateur le fait de savoir que to have a lie-down sous-entend un renvoi à l'objet “lit”. Utiliser to have a lie-down répond donc bien à un but communicatif précis :

(21) Parisian designer Jacques Rougerie obviously got rather tired of his new project --; designing a Seine river bus --, and thought he'd have a lie-down instead. (C8A 634)

32 To have a cuddle est également restreint sur le plan sémantique. Là où to have a cuddle renvoie aux câlins, à la tendresse, à la douceur, to cuddle, c'est aussi “ étreindre ", c'est-àdire " presser dans ses bras" (du latin stringere: "serrer" que l'on retrouve par ailleurs en anglais dans string, strong). Nous ne sommes pas tout à fait dans le même champ lexical. Partant, il est possible de percevoir to have a cuddle comme exprimant davantage la douceur, la tendresse. La structure est d'ailleurs souvent utilisée quand il est question d'enfants :

(22) 'Besides, a boy's allowed to have a cuddle when he hasn't seen his daddy, his papa, for a fortnight,' Victor said, tickling the toddler who dissolved into giggles.

(JY9 2653)

(23) You were very frightened, we had to get you up, read you a story, have a cuddle, put the light on. (KBW 6803)

(24) And you can have a cuddle on the sofa with Nanna. (KDE 64)

33 To have a chat fonctionne en parallèle avec to have a natter (ce dernier signifie aussi “bavarder"), chacune des structures ayant cependant son cadre d'emploi spécifique. To have a chat est de style familier, renvoie à un échange entre amis, le plus souvent à propos de choses qui ne sont ni sérieuses ni importantes. C'est " bavarder ", “ causer ", " parler de choses et d'autres". En ce sens, l'expression équivaut à to chat. Si ce n'est qu'elle se rapporte à un moment précis d'actualisation de to chat, comme to have a swim, to have a cry. Par ailleurs, elle se démarque de to have a natter, cette dernière renvoyant à un épisode plus long. Cela signifierait que la période temporelle tacitement délimitée par a ne serait pas équivalente dans les deux expressions. Cependant, rien ne l'explicite dans les structures, qui sont construites sur un mode identique. L'énonciateur va néanmoins savoir laquelle des deux renvoie à un événement plus long (ou laquelle renvoie à un événement plus court), notamment à partir de sa propre expérience de la langue. C'est bien la structure, dans son entier, qui est signifiante. To have a chat et to have a natter s'opposent l'une à l'autre, dans le même temps qu'elles s'opposent individuellement à to chat et to natter respectivement, comme tel a été le cas des autres structures rencontrées jusqu'ici :

(25) 'I think I'll go across and have a chat with that young fellow who came in the other day'; Phil said in a conversational tone to no one in particular and rushed out to Sister's Cooney's office. (A7J 478)

(26) The factory owners and shopkeepers would come and have a chat with you.

(B24 2642) 
(27) Perhaps Madonna should have a chat about the pop ethics with these young hopefuls. (CHB 2732) sème typique de $V$. Tel est le cas de to have a try. En effet, to try c'est: to attempt to do something, to make an effort in order to be able to do it, sachant que to attempt inclut l'idée de difficultés ou l'hypothèse d'un échec. Cette notion de difficulté et d'insuccès est absente de la structure en have a try qui ne considère que la démarche, et n'envisage pas de ne pas réussir à la mener à bien :

(31) I do hope that I have encouraged any nervous knitters to have a try at using the reader. (CA2 824)

(32) Annette says she wanted to encourage the boys to have a try at something different. (K21 3648)

(33) I have managed to breed my port Hoplo catfish and I thought I would drop you a line explaining how I succeeded so that other readers might have a try. (CGH 1718)

(34) Now, do you think we can make it to the post box, let's go and have a try, shall we? (KBW 15763)

Soit les expériences menées sont vivement préconisées $(31,32)$, soit elles ont été couronnées de succès (33), soit enfin elles ne paraissent pas insurmontables (34). La peur de l'échec ne transparaît pas de ces énoncés en have a try. L'information transmise par have a try ne va pas de soi. Cependant, l'énonciateur l'utilise toujours à bon escient. Cette spécificité bivalente se retrouve dans tous les emplois étudiés ici de have $a \mathrm{~V}$.

Malgré l'inconsistance soulignée plus haut quant à la nature exacte de ce qui suit have a dans ces unités, il semble clair d'après ces énoncés que l'on se dirige vers une nature moins nominale que verbale, et que l'appellation have $a V$ soit la plus appropriée car plus proche de la réalité. $V$ se met subtilement en place. Nous voyons ici que tous les critères invoqués par A. Wierzbicka n'entrent pas nécessairement en ligne de compte ensemble. Et que, aussi pertinents soient-ils, ils n'apparaissent pas tous dans chacune des occurrences. 


\subsection{Have a good $\mathrm{V} / \mathrm{N}$}

\section{détache de l'inventaire de A. Wierzbicka. Nous y trouvons to have a look, a read, a scribble, a} shower, a shave, a sip et a run.

les dictionnaires, les expressions sont toutes incluses dans les entrées respectives aux noms équivalents, et les définitions proposées sont laconiques : to have a look équivaut à to look, to have a shower équivaut à to shower, to have a shave équivaut à to shave. L'équivalence n'est toutefois pas proposée pour run (to have a run est différent de to run), et elle n'est même pas évoquée pour to have a read, to have a scribble, to have a sip (ce qui vient corroborer le peu d'occurrences recensées). Have a V/N est bien spécifique.

En revanche, la totalité de ces expressions se rencontre avec le schéma have a good $\mathrm{N}$, où le noyau est clairement utilisé comme nom cette fois (prémodifié par l'adjectif good) ${ }^{9}$. Cela a deux conséquences.

\subsection{1.}

La première conséquence, c'est que sans good, on retourne à un schéma en have $a V$ (et non pas en have $a \mathrm{~N}$ ) et, contrairement à ce qu'affirment les dictionnaires, la structure fonctionne alors comme celles étudiées ci-dessus : elle permet de transmettre un message qui est absent de $V$ :

(35) The testator had made a will, but then opened it to have a look at it. (B2P 765)

(36) May we just have a look down here? (ADM 1409)

(37) Let's have a look at just some of these. (CDK 345)

(38) Have a look out there at the rock on the left of the cove opening. (JY6 785)

Le premier énoncé contient une idée de but, les trois derniers contiennent une restriction : on " regarde", on " jette un œil à ", une chose en particulier. Le procès vise à atteindre un objectif.

(39) Get a good book --; have a read. (C8A 428)

(40) Have a read through them at your leisure. (GY4 1284)

(41) You shoot me when you have a read of that. (HDH 463)

(42) Have a read of my newspaper. (J13 1415)

(43) Have a sip of Brandy. (C9R 397)

Il est évident que l'on ne boit pas du cognac comme on peut boire de l'eau, et que la quantité de cognac (eau-de-vie) versée ne sera, a priori, pas aussi importante qu'une boisson alcoolisée. D'où, peut-être, le non emploi de have a drink ici.

Have a run enfin, d'emploi plus rare et non répertorié dans les dictionnaires, semble être créé pour être utilisé parallèlement à have a walk. Une différence existe cependant entre les deux structures. Tandis que have a walk est sans finalité, have a run peut (mais ce n'est pas systématique) viser un but particulier. Les exemples (44) et (45) illustrent les deux types d'emploi :

(44) 'Come on, let's go outside and have a run about.' (KB8 9331)

(45) 'I've heard, the people that are local, just have a run out on a Sunday afternoon

to find out where it is.' (KM5 404) 
2.2.2. qu'il se démarque de have a $N$ type have a house. Une relecture des caractéristiques propres à ces expressions mises en avant par A. Wierzbicka ${ }^{12}$, associée à l'examen de leur cadre d'emploi, mettent en évidence leur portée pragmatique inhérente. Il est à chaque fois question de l'expression d'un commentaire marqué sur le sujet à l'attention du coénonciateur. Ainsi,

- Le faible pourcentage des occurrences n'est pas révélateur d'un manque d'intérêt pour la construction ou d'un poids argumentatif incertain de celle-ci. Il n'enlève rien à leur poids sémantique. C'est au contraire, comme dans d'autres domaines, leur rareté qui fait leur portée. Chaque utilisation n'en sera que plus marquante, précisément parce qu'elle n'est pas systématique. 
- Le style (très) familier dont elles sont typiques indique bien la portée pragmatique de ces constructions. Ce n'est pas dans des situations formelles que l'on aura envie de transmettre quelque chose de personnel. Le langage formel ne laisse que peu de place à l'individuel. Le style est familier car le message touche, traite de personnes proches ou de personnes pour lesquelles l'énonciateur a un intérêt particulier.

- Il en est de même du fait que ces constructions soient rétives à un emploi technique. Parce qu'avec elles nous sommes dans l'échange humain. Elles impliquent une perspective subjective fondée sur l'expérience $^{13}$. Est-il uniquement question de l'expérience du sujet grammatical, ou de celle, commune, à l'énonciateur et au co-énonciateur ? $^{14}$

- La différence de sens entre les constructions et le verbe correspondant souligne l'existence d'un désir de transmettre un message spécifique. Ainsi R. Huddleston (2002 : 292) indique-til à propos de have a lie-down :

The light verb ${ }^{15}$ version is more specific. For example, "he had a lie-down" is used when the purpose of lying down is to rest - not, for instance, to undergo a medical examination.

51 Cela suppose donc que lorsque l'énonciateur crée he had a lie-down, il en connaisse les particularités sur le plan sémantique, et qu'il en soit de même pour son co-énonciateur (ou que ce dernier soit en mesure de reconstruire ces particularités).

- La différence aspectuelle associée à have $a V^{16}$ est en fait recherchée. Ce qu'il faut communiquer, c'est précisément la limite du procès. Celle-ci prend tout son sens au regard du sujet auquel la construction est rapportée dans la situation de communication.

- Ce qui se passe dans have a $V$ sans but externe (type John had a read, Go outside and have a play), c'est que le sujet interprète et souligne $^{17}$. Puisque le sujet est le seul bénéficiaire du procès, nous pouvons nous demander quel est son besoin de le souligner, sinon pour en informer quelqu'un d'autre?

- Avec les verbes de perception, have $a \mathrm{~V}$ souligne le caractère cognitif du verbe de perception ${ }^{18}$. Nous retrouvons la problématique du but précis propre à la construction.

- Dans have a $V$, l'action ne peut être décrite que du point de vue de l'agent, tout en sachant que le bénéfice pur n'est pas la seule fin envisagée (alors que c'est là la problématique majeure de la construction mise en avant par A. Wierzbicka). Il n'est par conséquent pas uniquement ni exclusivement question de quelque chose de "bon / plaisant" pour le sujet. La construction est là pour dire autre chose.

- Des actions d'ordinaire instantanées (sneeze, cough) ne peuvent être rapportées dans le schéma have a $V$ que si elles sont plus longues que la normale, ou si elles sont répétées ${ }^{19}$. Cet argument mène à la même conclusion que pour $h$.

- A bite, a chew, a lick n'affectent pas l'objet outre mesure (to have a bite of his sandwich). Donc have a $V$ est possible car seule l'orientation sujet prévaut. En revanche, eat, swallow, devour affectant tout ou partie certaine de l'objet, leur apparition dans le schéma have a $V$ est impossible. D'où l'agrammaticalité de ${ }^{*}$ have an eat ${ }^{20}$. Il est possible d'évoquer une autre explication à cette non recevabilité. Il n'est en effet “ pas normal " de ne pas manger quelque chose en entier. Si nous avons have a bite / lick / sip, c'est bien pour indiquer que le procès est caractéristique en ce sens qu'il ne constitue pas un but premier. En s'exprimant de manière primaire, soit l'on mange, soit l'on ne mange pas. La structure ne traiterait en rien du fait de se nourrir, elle introduirait une manière de faire.

- Have a wash / shave entrent dans le type qui recouvre le champ lexical des soins corporels qui bénéficient au sujet $^{21}$. Le bénéfice en question n'est autre qu'une amélioration de l'état antérieur de ce même sujet. C'est cela qui constitue la spécificité du message. 
- “The 'have a V' frame minimizes any possible effect of the action on the patient or partner; but it also trivializes the importance of the action from the point of view of the agent "22. Voici mentionné l'intérêt pour l'énonciateur de créer have $a V$. En réalité, le procès peut effectivement être considéré comme banalisé, si l'on comprend que ce n'est pas le procès dénoté par $\mathrm{V}$, en tant que constituant isolé, qui importe, mais bien l'ensemble have a V. avec have a $N$. Précisément parce que l'on n'est pas dans la configuration have a $N$. La lecture habituellement faite avec have est modifiée. Le retour au sujet est davantage marqué, car la structure dit ce retour (qui transparaît dans les concepts de bienfait, de plaisir, de bénéfice). moyen, notamment en raison même de la relation de localisation que have met en place. Have est utilisé chaque fois que l'élément repéré est différent de l'élément repère. L'on ne peut localiser des notions qui sont partie intégrante, par nature, du repère. Or notre repère est un animé humain, pour lequel boire, se laver, marcher, courir, regarder, etc., sans être définitoires, lui sont naturellement associés ${ }^{24}$. D'où le hiatus de surface qui se crée à la prise de connaissance de have a $V$. La structure est à la limite de l'acceptabilité, en ce sens qu'elle se rapproche de *S has a mouth / has hands... (où $S$ est animé humain), 
apragmatique parce que redondante, voire pléonastique. Ce premier caractère fait que $S$ has $a V$ retient, par définition, l'attention ${ }^{25}$.

Parallèlement, nous remarquons également une autre caractéristique de have $a V$, qui est que la structure ne se rencontre pratiquement jamais à la voix passive. Ceci s'explique cependant si nous acceptons le rapprochement avec le moyen, étant donné que le moyen est à l'origine du passif. On ne peut passiver quelque chose qui véhicule les propriétés, même atténuées, du passif.

Sur le plan interlocutif, have $a V$ témoigne d'un phénomène d'explicitation du retour vers le sujet que traduit la structure transitive have a $\mathrm{N}$. En dépit d'une apparente identité morphologique (d'autant que $V$ et $\mathrm{N}$ sont souvent liés par une relation de dérivation horizontale), have a $\mathrm{V}$ insiste plus sur le sujet que ne le fait have a $\mathrm{N}$. A cet instant précis de la situation de discours, l'énonciateur estime que la chose ainsi rapportée au sujet doit ou mérite d'être soulignée (parce que c'est nouveau, bien, trop bien, pas bien, rare, habituel, étonnant, gênant, banal, agaçant, etc..), à l'attention du co-énonciateur.

Have a $V$ tirerait son sémantisme et ses particularités non pas de sa ressemblance avec have a $\mathrm{N}$, mais bien de la différence que la structure entretient avec celle de base. La totalité des effets de sens de have a $V$ ne naîtrait pas tant de la somme de ceux de have $+a+$ $V$ que de l'irrégularité que la structure présente dans le système par rapport à have $a \mathrm{~N}$. Irrégularité que l'énonciateur sélectionnera à chaque fois qu'il souhaite souligner le sujet davantage que ne peut le faire une localisation " simple " en have a $N$. Chose étonnante, le co-énonciateur va interpréter, décoder cette intention avec justesse.

61 Nous pouvons schématiser le système obtenu, système à trois composantes dont chacune illustre le lien entre formes grammaticales et spécificité croissante du message :

- Have a $N$ 區 SVO - ordre typique de l'énoncé anglais ; localisation pure.

- A good / nice $N$ 唒 have a good / nice $N$ 嘼 l'énonciateur reconstruit une structure SVO à l'attention du co-énonciateur; petite déviance par rapport à 1: structure qui indique l'importance de l'objet pour le sujet.

- have $a V$ 䁌 nouveau schéma qui, à la fois, réintègre et explicite la localisation à l'attention du co-énonciateur ${ }^{26}$.

\section{Conclusion}

62 La locution have a $V$ (type have a drink) peut se prêter à une lecture globale, qui permet d'affirmer, de souligner la valorisation du sujet qu'opère la localisation. Participant donc tout à fait de la localisation, cette analyse globale est néanmoins considérée ici d'un point de vue interlocutif.

Il apparaît ainsi que la valeur en discours de la structure have $a V$ pourrait être davantage due à ce qui la distingue de have $a N$ (type have a house) plutôt qu'à ce que les deux formes ont en commun. De deux constructions a priori semblables naissent deux valeurs différentes qui s'appuient sur l'unique opération de localisation. Avec have a $\mathrm{N}$, l'information passe par la mise en avant du sujet. Avec have a $V$, l'énonciateur souligne la valorisation du sujet. Une structure de base sert de tremplin pragmatique à une seconde structure. Et have a $V$ d'illustrer la rencontre en situation de la grammaire et de la pragmatique. 


\section{BIBLIOGRAPHIE}

\section{Source des exemples}

Abbey Life training session (21/01/1994), employee training (Business). [KM5 404]

Abington (1993), Central TV. [K21 3648]

BACHELOR, M. (1988), Forty plus, Herts, Lion Publishing plc. [BLW 956]

Best (1991), London, Gruner \& Jahr (UK). [C8A 428; C8A 634]

Daily Telegraph (4/11/1992). [AJY 2227]

DUDLEY EDWARDS, R. (1993), Clubbed to Death, London, V. Gollancz Ltd. [HTG 1197]

ELLIS, A.T. (1993), Pillars of Gold, London, Penguin. [G1D 2444]

FOX, W.L. (1991), Willoughby' Phoney War, The Book Guild Ltd. [ACE 701]

HEDDERWICK, M. (1991), Highland Journey, Edinburgh, Canongate Press. [B1N 1568]

HILL, S. (1969), Gentleman and Ladie, London, Hamish Hamilton Ltd. [AD1 1726]

HOWARD, S. (1991), Conspiracy of Love, Richmond, Surrey, Mills \& Boon. [JKT 1644]

JAMES, R. (1993), Payback, London, Voctor Gollancz Ltd. [J13 1415]

James Whale phone-in radio broadcast (30/10/1993). [HUV 446]

LINDSAY, K. (1980), British Intelligence Services in Action, Dundalk, Ireland, Dunrod Press. [CCC 438]

Machine Knitting Monthly (1992), Maidenhead, MKM Ltd. [CA2 824]

Mc CALL, R. (1992), Hearing Loss. A Guide to Self-Help, London, Robert Hale Ltd. [C9R 397]

MORTIMER, J. (1988), Summer"s Lease, London, Penguin; [FB9 830]

Neighbourhood Watch talk: Crime Prevention. [GY4 1284]

OLDFIELD, E. (1993), Sudden Fire, Richmond, Surrey, Mills \& Boon. [JY9 2653]

Oral history project: interview. [K6M 504]

Practical Fishkeeping (1992), Petersboroughs, Cambs, EMAP, Pursuit publishing LTD. [CHG 1718]

Recorded conversations (1991: 3-5/06 [KDE 64]), (1992: 10-15/01 [KC3 389]; 10-17/01 [KBX 687];

31/01-7/02 [KB2 1568]; 13-20/03 [KBW 6803; KBW 8770; KBW 15763]; 3/04 [KB8 9331]), (1993 dates unknown [KDY 1041; KPG 4351])

SHARP, S. (1987), Falling for Love, London, Virago Press Ltd. [FU1 2407]

SILVERTON, P. \& MATLOCK, G. (1990), I Was a Teenage Sex Pistol, London, Omnibus Press. [A6E 1200]

STOKER, L. (1991), Having It All, London, Bloomsbury Publishing Ltd. [CDK 345]

Suffolk Sound Archive oral history project: interview (leisure), (2/04/1987). [HDH 463] 
The Daily Mirror (1992) [CH1 5996]

THOMPSON, E.V. (1992), Wychwood, London, Headline Book Publishing plc. [HHC 1054

WILDER, Q. (1993), One Shining Summer, Richmond, Surrey, Mills \& Boon. [JY6 785]

\section{Références bibliographiques}

ALBRESPIT, J. (2002), “ Nominalisations de type a laugh, a win ”, in C. Delmas, Construire \&

Reconstruire en linguistique anglaise, Syntaxe et Sémantique, C.I.E.R.E.C. Travaux 107, Saint-Etienne, Publications de l'Université de Saint-Etienne, p. 47-63.

ARISTOTE, La Métaphysique, trad. De Jules BARTHELEMY-SAINT-HILAIRE (1991), Agora, Presses Pocket, Cox \& Wyman Ltd.

BOUSCAREN, J. (1982), “ Have opérateur de localisation ”, in Cahiers de Recherche en Grammaire Anglaise, 1, Gap, Ophrys, p. 53-72.

BOISSON, C. (1987), “ Anglais Have, Français Avoir et l'empathie ”, in la Transitivité, domaine anglais, C.I.E.R.E.C, Travaux LII, Saint-Etienne, Publications de l'Université de Saint-Etienne.

CELLE, A. (2003), “ Constructions verbo-nominales atéliques et types de procès ”, in J.-M. Merle (dir) Mélanges en l'honneur de J. Guillemin-Flescher. Gap, Ophrys.

Collins Cobuild English Language Dictionary (1992), Glasgow, HarperCollins Manufacturing.

COTTE, P. (1998), “ Have n'est pas un verbe d'action : l'hypothèse de la réélaboration ”, in A. Rousseau, La transitivité, Lille, Presses Universitaires du Septentrion, p. 415-439.

HUDDLESTON, R. (2002), The Cambridge Grammar of the English Language, Cambridge, Cambridge University Press.

LE GUAY, E. (1995) Recherches sur le Past Perfect en anglais contemporain. Thèse non publiée, Université de Paris IV - Paris Sorbonne, 430 pages.

Macmillan English Dictionary (2003), Oxford, Macmillan Publishers Ltd.

Online Etymology Dictionary

PERNES, S. 198 ? “ Have / Avoir”, Mémoire de Maîtrise, Université de Bretagne Occidentale, Brest, 174 pages.

QUIRK, R. et al. (1985), A Comprehensive Grammar of the English Language, Longman.

ROUSSEL, E. (1999), “ She had been healthy and beautiful when he married her " Anglophonia/ Sigma $\mathrm{n}^{\circ}$ 6, Université de Toulouse-Le Mirail, Presses Universitaires du Mirail, Toulouse, p. 235-258.

ROUSSEL, E. (2003b), “ Un autre regard sur la répartition des rôles entre as et like dans la construction de la comparaison " CORELA - Cognition, Représentations, Langages, vol 1, n 2. Accessible à l'adresse suivante : http://revue-corela.org

ROUSSEL, E. (2004), “ Le commentaire associé au passif anglais ”, Les Cahiers du CRISCO, n 15, Caen.

ROUSSEL, E. (2005a), “ De la valeur du commentaire passif anglais ”, in Parcours linguistiques, Etudes réunies par G. Girard-Gillet sous la direction de L. Roux, C.I.E.R.E.C. Travaux 122, SaintEtienne, Publications de l'Université de Saint-Etienne, p. 271-288. 
WIERZBICKA, A. (1988), “ Why can you have a drink when you can't * have an eat ? ", The Semantics of Grammar, Amsterdam, John Benjamins Publishing Company. p. 293-357

\section{NOTES}

1. Entre autres récemment J. Albrespit (2002) et A. Celle (2003).

2. "And since the agent is also a potential experiencer, the heightened emphasis on the agent naturally draws attention to the subjective dimension of the action - to the agent's intentions, wishes and feelings." (Givón 1979: 337)

3. A noter l'introduction de good qui souligne l'interprétation de time comme nom. Tout comme nous pouvons avoir a good swim. Nous y reviendrons.

4. On ne peut à l'évidence occulter le rôle de a qui va singulariser et délimiter $V$, ne suggérant ainsi qu'une actualisation car il met ce qu'il introduit entre des frontières. Il permet de construire une occurrence de la notion verbale (exemple: He had a drink), et en ce sens l'expression ne peut plus exprimer une propriété du sujet comme tel est le cas avec he drank.

5. Voir également sur cette construction l'analyse de A. Celle (2003: 222), selon la Théorie des Opérations Enonciatives. Dans cette structure, have recentre le repérage autour du sujet et introduit une discontinuité selon que le procès dénoté par BV est télique ou atélique.

6. Critères classés principalement selon le type de procès dénoté par $V$ et sa nature transitive ou non. D'où les dix sous-groupes suivants: have a walk, have a look at, have a try, have a cough, have a bite, have a drink, have a kick, have a wash, have a kiss et have a chat.

7. Source BNC ou corpus personnel. Les références exactes sont données dans la bibliographie.

8. Il est intéressant de noter que $a$ n'a rien à voir avec la petite quantité, comme indiqué dans la note 4. Pour renvoyer à la petite quantité de liquide, l'expression utilisée est to take a drink (of something).

9. Nous retrouvons swim, cry, cuddle et lie-down qui entrent également dans cette catégorie. De même que bitch, non étudié par A. Wierzbicka.

10. L'adjectif ne renvoie pas systématiquement et exclusivement à ce qui est "bon " dans ce type d'exemples. Son sémantisme peut s'étendre à ce qui est "complet" (thorough), comme tel est le cas avec to have a good shower par exemple. C'est alors l'impression de complétude qui procure un bienfait.

11. “" expressions like have a walk, a lie-down, a swim imply that the activity is enjoyable, or potentially good for the agent." p. 301.

12. Nous reprenons les arguments énumérés plus haut (qui sont ici soulignés).

13. A. Wierzbicka, p. 297.

14. Nous noterons avec intérêt les remarques de A. Celle (2003: 220): "Pour construire une occurrence singulière, l'énonciateur doit pouvoir le repérer par rapport à un type" et J. Albresprit (2002: 60-61) : "Have a fall apparaît dans des contextes (hippiques, techniques, médicaux, etc.) où l'occurrence typique est “interprétable directement par un coénonciateur" ".

15. Sa dénomination de $V$ dans have a V. C'est moi, E.R., qui souligne.

16. A. Wierzbicka, p. 297.

17. Idem.

18. A. Wierzbicka, p. 302.

19. Ibid., p. 312.

20. Ibid., p. 314. Ils s'opposent en cela à have a sandwich, have a cake, have a steak, a whisky, a cigarette, davantage tournés vers la consommation de l'objet et non pas vers ce que le sujet en retient. 
21. Ibid., p. 326.

22. Ibid., p. 332.

23. Schéma motivé par le fait que l'ordre naturel de représentation des choses en anglais va de l'agent vers le patient, ordre que reflète le principe même de la transitivité: “The term 'transitive' derives from Latin tran 'across' + ire 'go' - it reflects the idea that in an elementary example like Ed killed Bill the action 'goes from‘ Ed to Bill." (R. Huddleston, 1986 : 192)

24. Ce sont des notions que le latin exprimait à l'aide du moyen. C'est typiquement la problématique du retour vers le sujet, du bénéfice pour le sujet. Voir E. Roussel (2004 et 2005a).

25. C'est, à mon sens, le même phénomène sous-jacent qui est à l'origine de la portée du slogan publicitaire bien connu : Have a break, have a kit-kat, où des notions auxquelles on ne s'attend pas sont intégrées dans un schéma commun have a $N$, avec un produit autre que les classiques have an ice-cream ou have a cake. C'est l'exception qui est soulignée. Voir en outre l'impératif comme mode illocutoire explicitement tourné vers le co-énonciateur.

26. A. Celle (2003 : 223) et moi-même nous accordons sur ce point: “ [En anglais, il existe donc un autre mode de construction de l'occurrence, par la médiation d'un type commun à l'énonciateur et au coénonciateur, qui permet d'évaluer directement sa conformité à ce type, et qui laisse une possibilité de jeu autour de l'entrée dans le domaine.] Ce mode aoristique suppose que le qualitatif soit de fondation dans la construction de l'occurrence, et que l'énonciateur soit dans une position décrochée. " C'est moi qui souligne.

\section{RÉSUMÉS}

L'article développe l'hypothèse d'une analyse de la séquence Have a $\mathrm{V}$ en termes de bloc sémantique qui prendrait, entre autres, sa signification au regard de l'autre bloc dont il se rapproche et s'éloigne à la fois, c'est-à-dire Have a N. L'opération de localisation sous-jacente aux deux constructions permet de mettre en évidence deux valeurs que se partagent have a $\mathrm{N}$ et have a $\mathrm{V}$, la seconde construction ayant en outre une portée pragmatique bien spécifique qui semble codifiée par la langue, à tout le moins perçue comme telle par les utilisateurs. Nous proposons un examen de ce code.

This paper deals with the Have a V construction, which is here mainly considered as a semantic unit. I will assume that its meaning is due to the similarities and differences that the structure bears with the Have an $\mathrm{N}$ construction. They both exemplify an operation of location which leads to two different values and which, in the case of the Have a V structure, has clearly to do with pragmatics. Strangely enough, speakers always use the construction on purpose, as an established language code. We intend to show how this code works.

\section{INDEX}

Mots-clés : bloc sémantique, localisation, norme, hiatus, explicitation, communication, pragmatique 
AUTEUR

EMMANUELLE ROUSSEL

Université de Caen - CRISCO (FRE 2805) 